\title{
Overview of Dynamic Testing of Ground Support
}

\author{
J. Hadjigeorgiou Université Laval, Canada \\ Y. Potvin Australian Centre for Geomechanics, Australia
}

\begin{abstract}
This paper provides a critical review of dynamic testing techniques used for understanding and quantifying the performance of ground support systems. This review focuses in particular on review of simulated rockburst experiments in Canada, Australia and South Africa. Furthermore, the different laboratory testing rigs are listed along with their characteristics and their advantages and disadvantages. The paper concludes with recommendations towards developing a more unified strategy to understand and eventually forecast the behaviour of support systems under dynamic loads.
\end{abstract}

\section{Introduction}

Forecasting the response of ground reinforcement and support systems subjected to seismic activity and strong ground motion has received considerable attention in the last few years. This has led to efforts to investigate the performance of support systems under simulated rockbursts and the construction of testing rigs with the capacity to test reinforcement units and support systems under dynamic loading.

\section{Definitions}

The stability of a rock mass can be adversely affected by mining induced seismicity and rockbursts. Brown (2004) describes the process as that of excess energy released from around the source of the instability that propagates through the rock mass as a series of seismic waves. This results in induced dynamic stress and associated displacements within the rock mass. This paper provides an assessment of testing procedures to quantify the performance of support systems under dynamic loading. In an engineering context dynamic loading implies variation in time as achieved due to repeated loads, moving loads, impact loads, shock waves or seismic waves.

Three main types of dynamic testing are considered. Simulated rockburst experiments involve the monitoring of rock mass response subjected to a simulated seismic source. Drop test facilities apply an impact load on a reinforcement or support system and record its performance. Laboratory tests on core rely on applying dynamic loads to core samples.

\section{Laboratory tests on core}

The use of laboratory tests on cores as tools for rockburst prediction has been advocated by Mansurov (1993). Such tests often rely on acoustic emission records during failure to gain an insight on rock behaviour. It can be argued that a variation of this methodology can be used to study the behaviour of liners under dynamic conditions. Falconbridge has undertaken some preliminary tests to these purposes. The main attraction of this type of tests lies in the controlled laboratory environment as well as the relatively inexpensive set-ups. On the other hand the major limitations lie in the absence of similitude studies and appropriate techniques to extrapolate such results to the field. More specifically, the loading mechanism is questionable, the scale of the specimen studied are not representative of in-situ rock mass and only one component of the support system (surface support) is tested in a limited way.

\section{Simulated rockburst experiments}

The complex mechanisms and interactions of a rock mass with the different elements used in ground support systems cannot be accurately replicated in a laboratory environment. In-situ investigations provide better opportunities for studying the performance of ground support systems in resisting the dynamic load 
generated by mine induced seismic events. Seismic events are highly unpredictable in terms of time, location and energy release. Consequently, they provide a means of "passive monitoring" rather than being the source of energy in a controlled experiment. This has led to efforts to replicate the strong ground motion of mine induced seismic events using controlled blasting techniques. These simulated rockbursts are then used to test ground support systems under dynamic loads.

Simulated rockbursts submit ground support systems to strong ground motion generated by one or several carefully designed blasts. Test sites are often instrumented to assess the energy delivered by the blasts at the tested wall location, the energy absorbed by some of the ground support elements and the damage sustained by the supported rock mass. The principal objective of simulated rockburst experiments has been to assess the in-situ performance of ground support systems under dynamic loading. Other pursued objectives include the study of rock ejection, ground motion amplification at wall surface, obtaining quantitative data for modelling purpose, etc.

Although a controlled explosion can produce strong ground motion, it is recognised that there are fundamental differences between a blast and a rockburst. This has to be taken into consideration in the design of the in-situ tests and in the interpretation of the collected data. One of the main rock breaking mechanisms in a blast is associated with gas expansion whilst seismic events exclusively generate stress waves. One of the challenges of a simulated rockburst is to minimise the effect of gas expansion. Furthermore it should be noted that the typical ground motion generated by a seismic event can be quite different from that generated by a blast. The typical signature of a seismic event is initiated by a relatively low frequency compressive wave followed by a larger amplitude shear wave. Most blasts produce a higher frequency shockwave (compared to a seismic event) with the initial peak amplitude being attenuated with time.

The Geomechanics Research Centre (GRC) at Laurentian University has conducted a number of experiments to study the behaviour of ground support systems under dynamic loading, Kaiser et al. (1996) as part of the Canadian Rockburst Research Program (CRRP 1990-1995). Amongst this work, there is discussion of "passive monitoring" by instrumenting ground support elements (mainly rockbolts) at Lac Shortt mines, at locations where intense seismic activity was anticipated. Similar "passive monitoring" experiments were conducted at Inco's Creighton Mine to investigate the performance of shotcrete. It should be clarified that these experiments do not constitute "simulated rockbursts" for the purpose of this paper, and are not addressed further.

This section focuses on simulated rockburst studies where explosives were employed. The full details of each trial have been presented by Hadjigeorgiou and Potvin (2006). The following subsections provide a brief description of each trial.

\subsection{GRC CANMET Lab}

The GRC designed a pilot experiment at the CANMET Underground Laboratory facility near Val d'Or, Quebec. Strain gauges were installed on the shank of three mechanical anchor rockbolts and dynamic loads were generated by mining a drift adjacent to the instrumented bolts. Six geophones were installed in the immediate area ( 2 geophones near each instrumented rockbolt) to monitor the ground vibration generated by blasting the pilot rounds and slashing them.

The objective of the test was to "...evaluate whether ppv measurements (or prediction) could be used to estimate dynamic stresses induced in rockbolts by seismic vibrations and to investigate the relationship between measured ppv values and blast induced spalling damage of the rock surface”, Tannant et al. (1994a).

Although an approximate relationship between ppv generated by the blast and the dynamic strain induced in the rockbolt could be established, variations of an order of magnitude in the dynamic strain were recorded due to its sensitivity to local site effects. As the objective of the test was to verify whether the ppv generated by a dynamic load could be related to the peak strain transmitted to the rock reinforcement, the load generated by adjacent round blasting was kept low and did not test the performance of the ground support itself. However, the onset of damage (or spalling) of the unsupported rock mass surface exposed in between the bolts was observed for ppv values ranging from 1.0 to $1.2 \mathrm{~m} / \mathrm{s}$. 


\subsection{GRC Bousquet \#2}

This series of simulated rockburst experiments at Bousquet \#2 involved eight blastholes (assumed to be blasted one at a time) drilled at a shallow angle (approximately 20 degrees) behind a supported wall. Increasing the distance between the blasthole and the free face allows for a range of dynamic loads to be generated by a single blast, Tannant et al. (1994b). Blastholes were $11 \mathrm{~m}$ long and $38 \mathrm{~mm}$ in diameter.

Blastholes A and B involved $16 \mathrm{~m}$ long holes and were used predominantly as calibration tests for assessing the blast design and measuring the velocity of rock ejection. Wall surfaces for blasts A and B were not shotcreted. The blast design was described by Tannant et al. (1993): "The holes were toe primed and the last meter of each blasthole were stemmed with clay. The blastholes were pneumatically loaded with AMEX II, an ANFO based explosive."

The instrumentation program used up to nine geophones per test site, mounted on the surface of the shotcrete, as well as on the rock surface itself. Strain gauges were mounted on the shank of rockbolts and other gauges were imbedded in shotcrete to measure the peak strain. "Home-made" velocity probes were also used to measure the ppv transmitted to the wall surface. Block ejection velocity were estimated using high speed video camera images.

The main objective of the test was to establish a direct comparison between the performance of shotcrete and mesh and fibre reinforced shotcrete. Of further interest was assessing the reduction in volume of rock ejected achieved by reinforced shotcrete compared to a rock surface without shotcrete. This series of simulated rockbursts demonstrated that the velocity can double at the surface of the excavation due to the reflection of the seismic wave. Shotcrete kept its functionality at ppv of 1.5 to $2.0 \mathrm{~m} / \mathrm{s}$. At moderate velocities, both steelfibre and mesh-reinforced shotcrete performed well, but at high velocity, mesh-reinforced shotcrete outperformed steel-fibre shotcrete. It was also established that the extent of damage and volume of rock (and shotcrete) ejected was controlled substantially by the orientation of the dominant foliation in the rock mass.

This test highlighted some of the difficulties and possible limitations of simulated rockburst experiments in generating meaningful numbers for design purposes. The fact that rock fabric had such a strong influence on the results suggests that results may be site dependent. The amplification of the velocity at the surface of excavation is also emphasising the complexity of the mechanism by which the radiant energy travels in the rock mass and is transferred to the ground support system when it reaches the surface of an excavation. This should be kept in mind when assessing the validity of drop tests to simulate these mechanisms.

One of the concerns with this specific experiment is that the effect of gas generated by this blast has apparently not been minimised. This experiment is probably a relatively poor simulation of a rockburst. ANFO will generate a significant amount of gases and stemming the collar will promote the use of energy generated by gases being transmitted to the rock.

\subsection{CSIR Kopanang Test}

Under the SIMRAC project GAP530, the CSIR conducted a simulated rockburst experiment at a deep level gold mine (Kopanang) involving a comprehensive site instrumentation program (Hagan et al., 2001). The location of the instrumentation was determined on the basis of numerical modelling. A single blast involving $261 \mathrm{~kg}$ of ANFO was designed to deliver strong ground motion along a strike length of $30 \mathrm{~m}$ of a wellinstrumented drift. Five blastholes were drilled from an adjacent drift and subsequently charged. The blastholes were detonated with $10 \mathrm{~g} / \mathrm{m}$ detcord and primed with 2 powergel 816 emulsion cartridges. The blast was relatively far from the instrumented drive (more than $6 \mathrm{~m}$ ) to minimise the direct effect of gas in the surface damage creation process.

The instrumentation program was designed to provide data towards different objectives and included: 2 accelerometers (where maximum damage was expected); a 32 channel microseismic system (GMM); triaxial and uniaxial geophones mounted on surface and inside boreholes ( 8 wall mounted geophones in between 2 rockbolts); borehole camera; extensometers and high speed video filming.

The single blast used in this experiment generated velocities up to $3.3 \mathrm{~m} / \mathrm{s}$ with block ejection velocity of $2.5 \mathrm{~m} / \mathrm{s}$. The blast was recorded by the mine seismic system as an event of magnitude $\mathrm{M}_{\mathrm{R}}$ 1.3. The areas that 
suffered damage shown as HID (High Intensity Damage) and LID (Low Intensity Damage) were located directly adjacent to the blast and to the west of the instrumented area.

One of the objectives was to understand the influence of rock reinforcement on the response of the rock mass to dynamic loading. The distribution of velocity at the rock surface was measured between two rockbolts, using eight surface mounted geophones. This was used to interpret the consequence of the bolts absorbing the shockwave induced by blasting, and as such, damping the vibration in between the bolts. Lower velocities were anticipated near the bolts. The rockbolts were not instrumented. The focus was to measure the effect on the rock mass and not on the reinforcement as was the case in the somewhat similar experiment at the CANMET underground laboratory. This part of the experiment is documented in Haile and Lebron (2001). A second objective was to collect data to calibrate a seismic wave propagation simulation program. "The aim was to compare the motions generated by a full-wave elastodynamic model, with the waveform and regions of damage recorded in the experiment." Hildyard and Milev (2001). A third objective was to study the rock mass fracturing process generated by the strong ground motion from the blast, as described in Reddy and Spottiswoode (2001).

It was found that there is very little vibration damping from rockbolts measured at the surface of the excavation, which highlights the importance of surface support when dealing with seismic loading. The ejection of blocks at a velocity of $2.5 \mathrm{~m} / \mathrm{s}$ occurred without any of the rockbolts failing. A minimum ppv of $0.7 \mathrm{~m} / \mathrm{s}$ defined the damage threshold for this site experiment (rockbolts and no surface support). The modeling of strong motion wave propagation proved to be difficult due to the complexity of the source. An analysis of the broken fragment size distribution in the damaged area did not provide any useful data. The block shape was largely a function of the geology. Most of the damage was considered to be due to shakeout. Discontinuities that are open prior to a rockburst are likely to be mobilised during the event. Mining induced fractures in particular had the largest influence because of their intensity.

As a general comment, this experiment was set-up to investigate fundamental principles, rather than practical and directly applicable outcomes. If the results of the preceding numerical modelling had proven more successful, this could have provided a tool for extrapolating results from simulated rockbursts. Although such a tool would be highly desirable given that simulated rockbursts are logistically difficult and costly to undertake, the challenge in developing a model capable of realistically simulating a dynamic source, the wave propagation and the complex mechanisms involved is once again emphasised by this experiment.

\subsection{INCO}

Inco Ltd has been conducting research on surface support in mines, including shotcrete and Thin Spray-on Liners (TSLs). An important consideration has been to investigate the capacity of support systems submitted to dynamic loading. Of interest is a series of simulated rockburst experiments conducted underground at the 175 research facility (located at shallow depth, $27 \mathrm{~m}$ below surface). A series of five cross-cuts were set-up for testing along the 7630 drift. Both sides of the cross-cuts were prepared (ground support was installed) and provided 10 test sites. Most of the tests (except cutout \#3) involved blasting from parallel blastholes, as the source of dynamic loading.

Great care was taken to design a high density and high velocity detonation to minimise the production of gas and better simulate the shockwave of a seismic event. The amount of explosives used varied according to the amount of vibration required for individual tests. Typically, a series of D-90 Pentolite primers were loaded in each blasthole. The blastholes were left unstemmed to vent the small amount of gas produced by the blast. Because primers are very light explosive and slightly decoupled, the blasthole had to be positioned very close to the free face (within half a metre to one metre) to generate sufficient vibration (up to approximately $3 \mathrm{~m} / \mathrm{s}$ ).

In addition to visual assessment of damage assisted by a grid painted on each tested wall, the instrumentation included eight velocity sensors attached to rockbolts. From these eight point measurements, a contour map of vibration experienced at the rock surface could be drawn; 2 or 3 velocity probes were also mounted tight against the surface support. Laser scanning of the face was conducted before and after the blast.

Espley et al. (2002) described the objective of this series of tests as follows: “...to assess the response of surface support systems in typical dynamic blasting and seismic related environments." This series of 
simulated rockbursts allowed for a quantitative assessment of the "in-situ" resistance (expressed as a range of peak vibrations) of different surface support types. The test methodology appears to have been robust and the results easily interpreted. The vibration level varied along the surface tested and vibration contours could be drawn along the surface of the tested wall. As the surface was divided in one metre squares, a 5 by $5 \mathrm{~m}$ wall test provided up to 25 vibration data points.

However, as it was the case for previous simulated rockbursts experiments, it was found that results were very sensitive to rock mass structure. Therefore, any extrapolation to other sites (or other conditions) would require careful consideration and empirical calibration. The logistics of simulated rockbursts can be complicated, time consuming and costly. This limits the number of experiments that can be performed in practice, and requires major commitment from operations.

\subsection{Queen's University}

A Queen's University research project led by Professor James Archibald and sponsored by the Workplace Safety and Insurance Board of Ontario (WSIB) was initiated in 2001 to "...characterise the support capabilities of conventional and innovative spray-on lining materials for mitigating dynamic failure effects created by simulated rockbursts.” Archibald et al. (2003).

In the initial phase, the testing procedure was developed and in a subsequent phase various ground support systems were tested to assess their efficiency in mitigating the damage created by simulated rockbursts. Nearly 50 simulated rockbursts tests were conducted during the initial two phases of research. All the tests were conducted at the Camdem East Explosive Test Site, a surface facility near Kingston, Ontario. An outcrop of limestone measuring approximately 40 by $75 \mathrm{~m}$ was cleared and subdivided into rectangular panels $(4 \mathrm{~m}$ by $5 \mathrm{~m})$ to host individual tests. A $63.5 \mathrm{~mm}$ blasthole was drilled in the centre of each panel to a maximum depth of $2.72 \mathrm{~m}$. The blast was produced using St-Lawrence Explosives' Brutus 300 Emulsion, packaged in $1.2 \mathrm{~kg}$ cartridges $(60 \mathrm{~mm}$ diameter by $400 \mathrm{~mm}$ long). The holes were typically sub-graded with $0.56 \mathrm{~m}$ of gravel and stemmed with $1.22 \mathrm{~m}$ of gravel. Contrary to most of the previous tests, which relied on parallel blasting, these tests used crater blasting.

The instrumentation included four different Instantel blast monitors, with a maximum of seven individual sensors recording ground vibrations at distances between 1.74 to $84 \mathrm{~m}$ from the blast. In addition, each blast was filmed using a high speed video camera. Fourteen baseline unsupported trial blasts were conducted to study the limestone response to the dynamic loading induced by blasting.

The main objective of the project was to compare the capabilities of different support systems (reinforcement and surface support) in mitigating the dynamic failure created by a standard explosion aimed at simulating rockbursts. The large number of standard blasting tests allowed the comparison of the performance of different support systems. Conventional rockbolts and mesh alone did not prevent the ejection of rock fragments. All spray-on forms of ground support including shotcrete, fibrecrete and TSLs showed significant benefits in terms of mitigating rock damage effects from the blasts.

Access to a surface test facility eased the logistics of conducting simulated rockbursts tests. As a result, Archibald managed to carry out over 50 tests, which is much more than any other researcher. However, questions have been raised with regards to the validity of the methodology used in the tests.

Specifically, Swan (2003) argued that: "The experimental arrangement in a bedded limestone deposit is such that it would be virtually impossible to differentiate in time the effects of shock wave from gas expansion, so that the observed parameters such as heave height, heave radius, number of fractures and fracture lengths etc. are almost certainly a consequence of gas expansion, particularly after 40 milliseconds". Archibald responded to this criticism by arguing that the effect of gas expansion is precluded by using only the first 10 milliseconds after detonation in the rock fracture and displacement analysis. The success of this approach is, however, difficult to quantify.

\subsection{University of Western Australia}

The University of Western Australia undertook two series of simulated rockbursts at the Long Shaft mine in 2004, and in 2005 a third series was conducted at Mount Charlotte mine. The same methodology was used at all sites in order to assess different ground support systems' performance in different ground conditions. 
The general layout used for the UWA simulated rockbursts was somewhat similar to the Inco layout in that a "T" junction cross-cut was used to design a parallel blast, behind a supported wall. Two support systems, comprising reinforcement elements and a surface support, were installed side-by-side, each system covering approximately an area of 5 by $5 \mathrm{~m}$, located at a distance of $10 \mathrm{~m}$ from the turnout. This allowed a direct comparison of the performance of both support systems in the same ground conditions, when submitted to similar dynamic loading generated by blasting.

The UWA experiment utilised three separate and consecutive blasts to generate three levels of vibration that generated three sets of results for each test. The first blast was initiated from the central hole that was aimed at generating a maximum vibration of approximately $0.5 \mathrm{~m} / \mathrm{s}$. The second blast from the top hole generated approximately $1.5 \mathrm{~m} / \mathrm{s}$ and third blast from the bottom hole was aimed at creating severe damage by generating approximately $5 \mathrm{~m} / \mathrm{s}$. Consecutive blasts were considered to reflect the repetitive loading experienced in seismically active mines.

Care was taken to minimise the effect of gas generation by using high impact low gas generation packed emulsion explosives such as Dyno Powermite Advance and Orica Powergel Buster. The holes were left unstemmed to let the gas escape from the collar and the stand-off distance between the explosive and the tested wall was generous $(5 \mathrm{~m})$ compared to the Inco test $(<1 \mathrm{~m})$. Typical charges at Long shaft were respectively about $10 \mathrm{Kg}, 20 \mathrm{Kg}$ and $40 \mathrm{Kg}$ in holes \#1, 2 and 3. Most velocities achieved by the blasts were between 0.6 to $2.5 \mathrm{~m} / \mathrm{s}$ except for one blast that generated over $5 \mathrm{~m} / \mathrm{s}$ ). As generally lower than expected velocities were achieved, the charges were increased at Mount Charlotte to over $60 \mathrm{Kg}$ for the third blast. From the experience acquired to date with UWA's simulated rockbursts, it is felt that high velocities can be achieved without introducing gas effect, with charges exceeding $60 \mathrm{Kg}$ as well as by moving the stand-off distance closer (say $3 \mathrm{~m}$ ) from the supported face.

The typical instrumentation program included 12 observation holes $(3 \mathrm{~m}$ long) for borehole camera logging before and after each blast. Two triaxial geophones were installed in $2 \mathrm{~m}$ deep holes (one triaxial associated with each support panel tested) as well as 4 rockbolt-mounted geophones and 6 surface-mounted geophones. The seismic data were recorded by a 16 channel Impulse Microseismic monitoring and an eight channel Ground Motion Monitor (GMM) seismic monitoring system. Detailed mapping of the walls was done using the Sirovision system which also allows measurement of surface deformation by 'subtracting' fully digitised 3 dimensional images taken before and after the blast. All simulated rockbursts were recorded using a Canon MV750i digital video camera.

Heal (2005) states the objective of the UWA simulated rockburst trials were as follows: "By simulating rockburst damage using blasting, it is possible to gauge the performance of complete support systems (incorporating reinforcing retaining and holding elements as well as connections between the three) in situ, when subjected to strong ground motion."

Each test provided a direct answer as to which of the two support systems involved performed the best at the specific mine site. By compiling the results from these tests, Heal (2005) produced a series of preliminary graphs relating a range of energy sustained by individual support systems to a damage scale. Further tests in different ground conditions may eventually provide enough data to develop reliable guidelines on the resistance of support systems to dynamic loading.

As with the Inco tests, this type of simulated rockburst provides quantitative data on the resistance of ground support systems to dynamic loading. The tests are robust and the interpretation of the results is relatively straight forward. Each test site provided approximately 150 vibration measurements $(5 \mathrm{~m} \times 10 \mathrm{~m}=50 \times 1 \mathrm{~m}$ squares multiplied by 3 blasts). Extrapolation of results from one mine to another is not obvious. This would require a large number of tests involving a variety of ground support in a variety of ground conditions to develop robust empirical rules. The high cost and difficult logistics of performing a significant number of simulated rockbursts is the main drawback.

\subsection{Falconbridge}

Recent tests were reported in Andrieux et al. (2005). The objective of these trials was to obtain a direct comparison of existing dynamic resistant support systems currently used at Craig Mine and Kidd Creek 
Mine, against the 3M Mining Liner used with modified (resin-grouted) conebolts. A further objective was to obtain field data that could be used to calibrate a FLAC3D numerical model.

A total of 6 tests were conducted with three support systems; the Craig system, the Kidd Creek system and the 3M TSL, which were each tested twice. The Craig Mine standard for dynamic resistant support involves \#6 gauge weld-mesh screens, rebars, \#0 mesh-straps and conebolts. Kidd Creek uses fibre reinforced shotcrete and rebars and the TSL involves a coating of 3M TSL and conebolts. A "rehearsal trial" was performed to test the logistics and design parameters.

A typical test involved a single $102 \mathrm{~mm}$ diameter blasthole, drilled from the wall mid-height, slightly upward at +15 degrees, to a depth of $7.5 \mathrm{~m}$. Unlike the CSIR, Inco and UWA tests, which used parallel blastholes located behind the tested face, this test used a blasthole angled at 30 degrees from the face. The rationale for this design was to induce excessive damage to the collar area in order to vent the gas from the explosion. The expected result was a shockwave, relatively free of gas, hitting the area where the ground support was to be tested, away from the collar of the blasthole.

The bottom $2.5 \mathrm{~m}$ of the blasthole was charged with fully coupled Orica Apex Super $6000^{\mathrm{TM}}$ boostersensitive watergel cartridges. This is an equivalent charge weight of $26 \mathrm{Kg}$. The stemming distance varied from $2.3 \mathrm{~m}$ to $5.0 \mathrm{~m}$ depending on the test. The stand-off distance to the tested free face (burden) varied from $2.5 \mathrm{~m}$ to $3.75 \mathrm{~m}$.

In addition to the mine wide seismic system used at the Fraser mine, the instrumentation program dedicated to the simulated rockburst tests included a surface mounted triaxial geophone, a surface mounted uniaxial accelerometer, a high speed camera and for each test, one instrumented rockbolt to measure the dynamic strain experienced by the tendon.

Andrieux et al. (2005), states that: "The principal objective of these large scale tests, which were initially laid-out and planned by Falconbridge MTS personnel, was to simulate with explosive charges the effects of a large rockburst that would occur in the vicinity of a drift supported by three different ground support systems, in order to assess and compare the behaviour of each under strong dynamic loading". More specifically, it was aimed at simulating a seismic event magnitude +2.5 (Richter scale) producing in theory ground vibrations of $1.5 \mathrm{~m} / \mathrm{s}$ at the surface of a drive located $16 \mathrm{~m}$ away from the source.

One of the main conclusions from the test was that: "In a qualitative manner, it could be seen from post blast observations that all the support systems tested behaved quite well and withstood the strong ground motions they had been subjected to, in spite of the fact that many of the bolts yielded during the blast."

Andrieux et al. (2005) recognised the difficulties of using blasting to simulate rockbursts. In particular, they found that the issues of venting the gas, as well as the higher dominant frequencies generated by blasting (in comparison to a far field seismic event), are difficult to control and account for. The inclined blasthole geometry in particular was difficult to implement and generally provided variable and unexpected outcomes. More intense instrumentation programs such as the ones used at Inco, Long Shaft and Mount Charlotte may have provided more reliable quantitative results, but likely at a higher overall cost.

\subsection{Discussion}

The reported field trials had different objectives and as such, a comparison between the tests may be misleading. However, they all had the common objective of simulating rockbursts. Table 1 provides a comparison of the reviewed rockbursts simulations. Note that in Table 1, the dynamic load is represented by velocity, because these data were reported by most authors. However, energy, which accounts for the mass affected by the load, would be a better representation of the dynamic load.

Simulated rockbursts using a blast as the source of dynamic loads can test fully integrated ground support systems (reinforcement, surface support and connecting elements) in conditions similar to which they will be used. The interaction between the support elements and the in-situ conditions, including rock mass, confining stress, scale, geometry, etc, are arguably realistic and constitute one of the advantages of these types of tests. 
Table 1 Comparison of the dynamic load simulation methods used for each trial

\begin{tabular}{|c|c|c|c|c|c|c|}
\hline $\begin{array}{l}\text { Test } \\
\text { Denomination }\end{array}$ & $\begin{array}{l}\text { Dynamic } \\
\text { Load } \\
\text { Simulation }\end{array}$ & $\begin{array}{l}\text { Stand-off } \\
\text { Distance } \\
\text { (m) }\end{array}$ & $\begin{array}{l}\text { Max. } \\
\text { Velocity } \\
\text { Achieve } \\
\text { d (m/s) }\end{array}$ & $\begin{array}{l}\text { Appraisal } \\
\text { of Gas } \\
\text { Effect }\end{array}$ & Support Tested & Comments \\
\hline $\begin{array}{l}\text { GRC CANMET } \\
\text { Lab }\end{array}$ & $\begin{array}{l}\text { Pilot Round } \\
\& \text { Slash }\end{array}$ & $>6$ & $\begin{array}{l}1.0 \text { to } \\
1.2\end{array}$ & Negligible & Rockbolts only & $\begin{array}{l}\text { Velocity may } \\
\text { be too low to } \\
\text { test bolts } \\
\text { capacity }\end{array}$ \\
\hline $\begin{array}{l}\text { GRC } \\
\text { Bousquet\#2 }\end{array}$ & $\begin{array}{l}\text { Angled } \\
\text { blasthole } \\
\text { from face }\end{array}$ & $0-3.7$ & $\begin{array}{l}\text { High and } \\
\text { variable }\end{array}$ & High & $\begin{array}{l}\text { Integrated } \\
\text { systems } \\
\text { (shotcrete, } \\
\text { fibrecrete and } \\
\text { rockbolts) }\end{array}$ & $\begin{array}{l}\text { Possibly poor } \\
\text { simulation of } \\
\text { rockburst due } \\
\text { to gas effect }\end{array}$ \\
\hline CSIR Kopanang & $\begin{array}{l}\text { Parallel } \\
\text { blastholes, } \\
\text { large charge } \\
(261 \mathrm{Kg}) \\
\text { emulsion, } \\
\text { chocked- } \\
\text { blasted far } \\
\text { from face }\end{array}$ & $>6$ & 3.3 & Negligible & $\begin{array}{l}\text { Unsupported and } \\
\text { rockbolts only }\end{array}$ & $\begin{array}{l}\text { Relatively } \\
\text { good } \\
\text { simulation of } \\
\text { rockburst. } \\
\text { Velocity may } \\
\text { be too low for } \\
\text { dynamic } \\
\text { support testing }\end{array}$ \\
\hline Inco & $\begin{array}{l}\text { Parallel } \\
\text { blastholes, } \\
\text { small } \\
\text { charge close } \\
\text { to face }\end{array}$ & $<0.5$ & 0.5 to 3 & Negligible & $\begin{array}{l}\text { Integrated } \\
\text { systems } \\
\text { (shotcrete, TSL, } \\
\text { mesh and } \\
\text { rockbolts) }\end{array}$ & $\begin{array}{l}\text { Relatively } \\
\text { good } \\
\text { simulation of } \\
\text { rockburst. } \\
\text { Velocity may } \\
\text { be too low for } \\
\text { dynamic } \\
\text { support testing }\end{array}$ \\
\hline Queen's & $\begin{array}{l}\text { Crater } \\
\text { blasting }\end{array}$ & Approx. 1.2 & & High & $\begin{array}{l}\text { Integrated } \\
\text { systems } \\
\text { (shotcrete, TSL, } \\
\text { mesh, bolts) }\end{array}$ & $\begin{array}{l}\text { Possibly poor } \\
\text { simulation of } \\
\text { rockburst }\end{array}$ \\
\hline UWA & $\begin{array}{l}\text { Parallel } \\
\text { blastholes, } \\
\text { medium } \\
\text { charge }(10 \\
\text { to } 60 \mathrm{Kg}) \\
\text { emulsion, } \\
\text { blasted far } \\
\text { from face }\end{array}$ & 5 & $\begin{array}{l}>2.5 \\
\text { except } \\
\text { for one } \\
\text { blast }>5\end{array}$ & Negligible & $\begin{array}{l}\text { Integrated system } \\
\text { (fibrecrete, TSL, } \\
\text { mesh, bolts) }\end{array}$ & $\begin{array}{l}\text { Relatively } \\
\text { good rockburst } \\
\text { simulation. } \\
\text { High velocity } \\
\text { with no gas } \\
\text { effect was } \\
\text { achieved once }\end{array}$ \\
\hline Falconbridge & $\begin{array}{l}\text { Angled } \\
\text { blasthole } \\
\text { from face } \\
(26 \mathrm{~kg})\end{array}$ & 2.5 to 3.75 & 0.15 to 3 & $\begin{array}{l}\text { Negligible } \\
\text { further } \\
\text { from the } \\
\text { collar of } \\
\text { the } \\
\text { blasthole }\end{array}$ & $\begin{array}{l}\text { Integrated support } \\
\text { systems (mesh } \\
\text { and mesh-straps, } \\
\text { fibrecrete, TSL, } \\
\text { bolts) }\end{array}$ & $\begin{array}{l}\text { Angled } \\
\text { blastholes are } \\
\text { difficult to } \\
\text { control. } \\
\text { Velocities are } \\
\text { lower than } \\
\text { required to } \\
\text { damage } \\
\text { dynamic } \\
\text { resistant } \\
\text { support }\end{array}$ \\
\hline
\end{tabular}


A major concern in simulated rockburst trials is how to minimise the influence of gases. This stems from the fact that seismic events are pure stress waves and therefore, the presence of gases can skew the results. It follows that successful efforts would rely on the use of high impact low gas explosives, avoiding stemming the hole and leaving a "reasonable" stand-off distance (distance between the blast and the face). Unfortunately, most trials report that this has been difficult to achieve in practice. Nevertheless, recent efforts by Heal (2005), documented in recorded videos, suggest that it is possible to deliver high velocity tests $(>3 \mathrm{~m} / \mathrm{s})$, without significant gas contribution.

The second possible discrepancy between blasts and seismic events is the higher frequency of the shockwave produced by blasting compared to a typical large far field seismic event. This limitation cannot be overcome. The only alternative is to calibrate the results of simulated rockbursts against recorded rockburst case studies and passive monitoring experiments.

The direct comparison of support systems, installed in similar ground conditions and under similar levels of dynamic loading has been achieved in most tests (Bousquet\#2, Inco, UWA, Falconbridge). However, the Bousquet \#2 and the Inco tests have drawn attention to the influence of dominant geological structural features on the results. This highlights the problems associated with extrapolating test results from one site to another.

A large number of simulated rockburst tests in a variety of ground conditions may eventually provide enough data to generate robust empirical rules on the dynamic resistance of support systems. The main impediment to pursuing this goal is the relatively high cost and challenging logistics of conducting such tests.

\section{Review of testing rigs}

The impetus for testing rigs has been the need for repeatable tests that provide an insight into the performance and capacity of different reinforcement systems. There have been several discrepancies in the literature on the different rigs, their capacity and their performance. The first task was to identify the different rigs that have been reported and then establish their status. In order to clarify the somewhat incomplete or conflicting information in the public domain, the following list of facilities has been prepared, see Table 2.

The more important task of comparing the different testing rigs is complicated by the absence of a universal standardised testing procedure and reporting of data. It is necessary to appreciate the objectives behind the development and construction of each rig and the relative costs of the gained insight and information. In practice, it follows that a test facility would entail some form of a contract between user and operator. As such, it is necessary to clearly define the test procedures as well as the final product (presentation of results).

\subsection{Terratek}

The rig was constructed in 1978 at MiningTek in South Africa, with equipment originally procured from Terratek in the United States. With this rig, a hydraulic system is employed to pull the collar of a shortened bolt or push to the top end of a prop. The unit can be configured to test rockbolts in tension or shear and can assess the performance of both the reinforcing unit as well as the anchor mechanism of the system. At present time, the Terratek rig is, however, mostly used to test props in compression. The rig can also be operated in a quasi-static mode at a displacement of $30 \mathrm{~mm} /$ minute. The rig can accommodate props as long as 1.6 metres. Instrumentation is limited to displacement, piston velocity and force at the load cell attached to the collar.

Currently it is mostly used as a quality control measure to test the performance of props. It has been used in the past to test short (limited length) rockbolts (re-bar, smooth bar and wire cable) as reported in SIMRAC Project 616 (Güller et al., 2001). The tendons were anchored by clamping jaws, spaced at $1 \mathrm{~m}$. None of the tendons were grouted, and the loading velocities were relatively low (1 to $20 \mathrm{~mm} / \mathrm{sec})$.

The main advantages of the Terratek rig are: Low costs; Quick set-up allows up to three tests per hour (depending on length of props); can be configured to apply dynamic loads in compression, tension or in shear and the longevity and continuous operation. Its main limitations are: It can only test individual reinforcement units and not systems; Limited on the maximum length of a reinforcement unit that it can test; and limited instrumentation. 
Table 2 Comparison of testing rigs

\begin{tabular}{|c|c|c|c|c|c|c|}
\hline$\underset{\#}{\text { Rig }}$ & $\begin{array}{c}\text { Common } \\
\text { Name }\end{array}$ & Type & Sponsor & Ownership & Location & Status \\
\hline 1 & Terratek & $\begin{array}{l}\text { Uses } \\
\text { hydraulic } \\
\text { system }\end{array}$ & MiningTek & MiningTek & $\begin{array}{l}\text { MiningTek, } \\
\text { Johannesburg, } \\
\text { South Africa }\end{array}$ & Operational \\
\hline 2 & $\begin{array}{l}\text { SRK Drop } \\
\text { weight test } \\
\text { facility }\end{array}$ & Impact & SIMRAC & MiningTek & $\begin{array}{l}\text { MiningTek, } \\
\text { Johannesburg, } \\
\text { South Africa }\end{array}$ & $\begin{array}{l}\text { Can be made } \\
\text { operational on } \\
\text { a week's } \\
\text { notice }\end{array}$ \\
\hline 3 & $\begin{array}{l}\text { SIMRAC } \\
\text { Dynamic } \\
\text { Stope Test } \\
\text { Facility }\end{array}$ & Impact & SIMRAC & SIMRAC & $\begin{array}{l}\text { Savuka Mine } \\
\text { (AngloGold West } \\
\text { Wits Operations } \\
\text { Satellite training } \\
\text { centre), South } \\
\text { Africa }\end{array}$ & $\begin{array}{l}\text { Operational. } \\
\text { Managed by } \\
\text { SRK on behalf } \\
\text { of SIMRAC }\end{array}$ \\
\hline 4 & $\begin{array}{l}\text { GRC- } \\
\text { Laurentian }\end{array}$ & Impact & NSERC & Laurentian & $\begin{array}{l}\text { Laurentian } \\
\text { University, } \\
\text { Sudbury, Canada }\end{array}$ & Operational? \\
\hline 5 & $\begin{array}{l}\text { GRC- } \\
\text { Creighton }\end{array}$ & Impact & $\begin{array}{l}\text { Canadian } \\
\text { Rockburst } \\
\text { Research } \\
\text { Project }\end{array}$ & $\mathrm{N} / \mathrm{A}$ & $\begin{array}{l}\text { Inco Creighton } \\
\text { Mine, Sudbury, } \\
\text { Canada }\end{array}$ & Dismantled \\
\hline 6 & NTC & Impact & NTC & CANMET & $\begin{array}{l}\text { MRL, Ottawa, } \\
\text { Canada }\end{array}$ & Operational \\
\hline 7 & WASM & $\begin{array}{l}\text { Momentum } \\
\text { Transfer }\end{array}$ & Sponsors & WASM & $\begin{array}{l}\text { Western Australian } \\
\text { School of Mines, } \\
\text { Kalgoorlie, Western } \\
\text { Australia }\end{array}$ & $\begin{array}{l}\text { Operational. } \\
\text { Stage } 2 \text { under } \\
\text { development } \\
\text { for the next } 3 \\
\text { years }\end{array}$ \\
\hline 8 & $\begin{array}{l}\text { Wedge-Block } \\
\text { Loading } \\
\text { Device }\end{array}$ & Impact & $\begin{array}{l}\text { SRK } \\
\text { Duraset }\end{array}$ & $\begin{array}{l}\text { SRK/ } \\
\text { Duraset }\end{array}$ & $\begin{array}{l}\text { Duraset Site, near } \\
\text { Johannesburg, } \\
\text { South Africa }\end{array}$ & Operational \\
\hline 9 & MIRARCO & Impact & & MIRARCO & $\begin{array}{l}\text { Laurentian } \\
\text { University, } \\
\text { Sudbury, Canada }\end{array}$ & Operational \\
\hline
\end{tabular}

\subsection{SRK drop weight test facility}

The test rig was developed by Steffen Robertson and Kirsten Consultants (SRK) under financing from the Safety in Mines Research Advisory Committee (SIMRAC) Project GAP 221 (Ortlepp and Stacey, 1997). The objective was to determine the performance characteristics surface support systems (wire mesh, lacing and shotcrete) used in South African mines under dynamic loading. This resulted in the design and construction of a drop weight test facility with the capability of input energies up to $70 \mathrm{~kJ}$ and impact velocities up to approximately $8 \mathrm{~m} / \mathrm{s}$, conditions representative of severe rockbursts. The first configuration of the rig is described in Ortlepp and Stacey (1997). This report is referred to as set-up \#1 (Figure 1).

A further configuration of the rig was undertaken in 1998 by Ortlepp and Stacey as part of SIMRAC Project GAP 423. Set-up \#2 expanded the capacity of the rig to undertake dynamic tensile loading on rock reinforcement units (including $16 \mathrm{~mm}$ rebar shepherd crooks, $16 \mathrm{~mm}$ diameter smooth bar shepherd crooks, 
de-stranded hoist rope "slings", $18 \mathrm{~mm}$ compact strand cable, $39 \mathrm{~mm}$ diameter split set bolts and Swellex bolts), Figure 2.
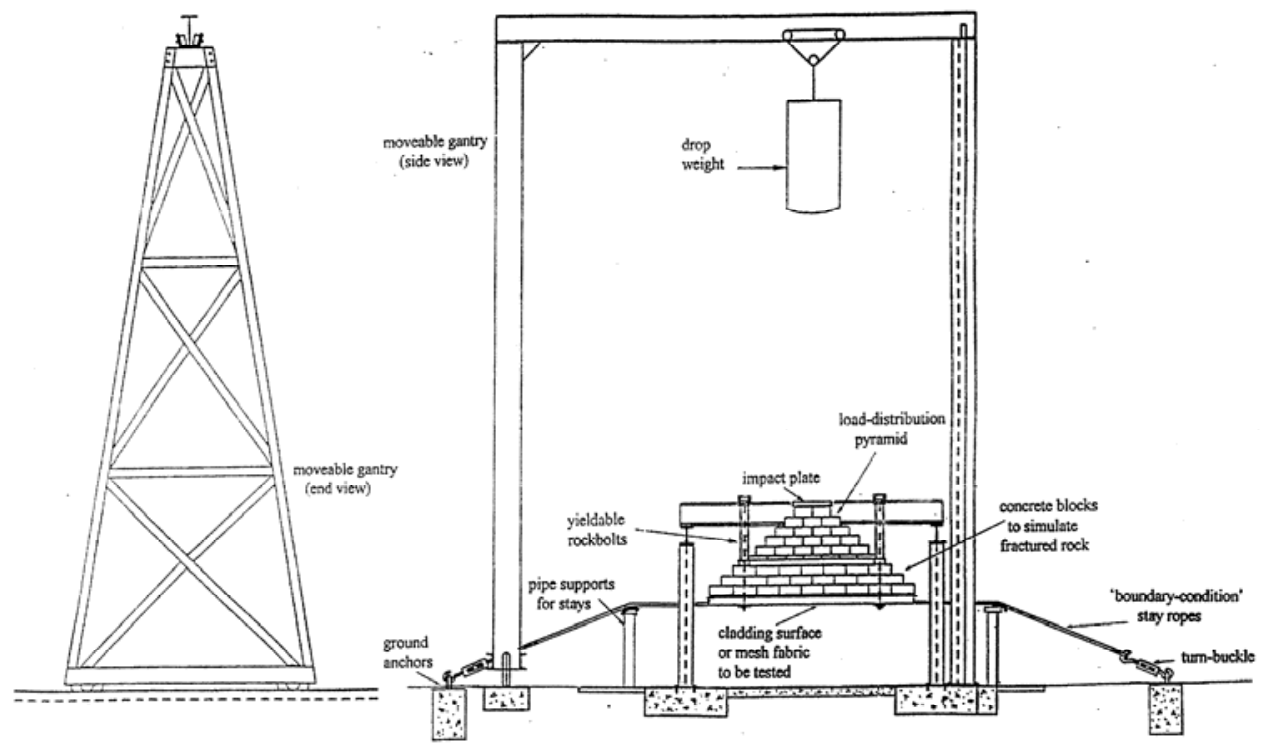

Figure 1 Sketch of the test facility for rock support, after Ortlepp and Stacey (1997)

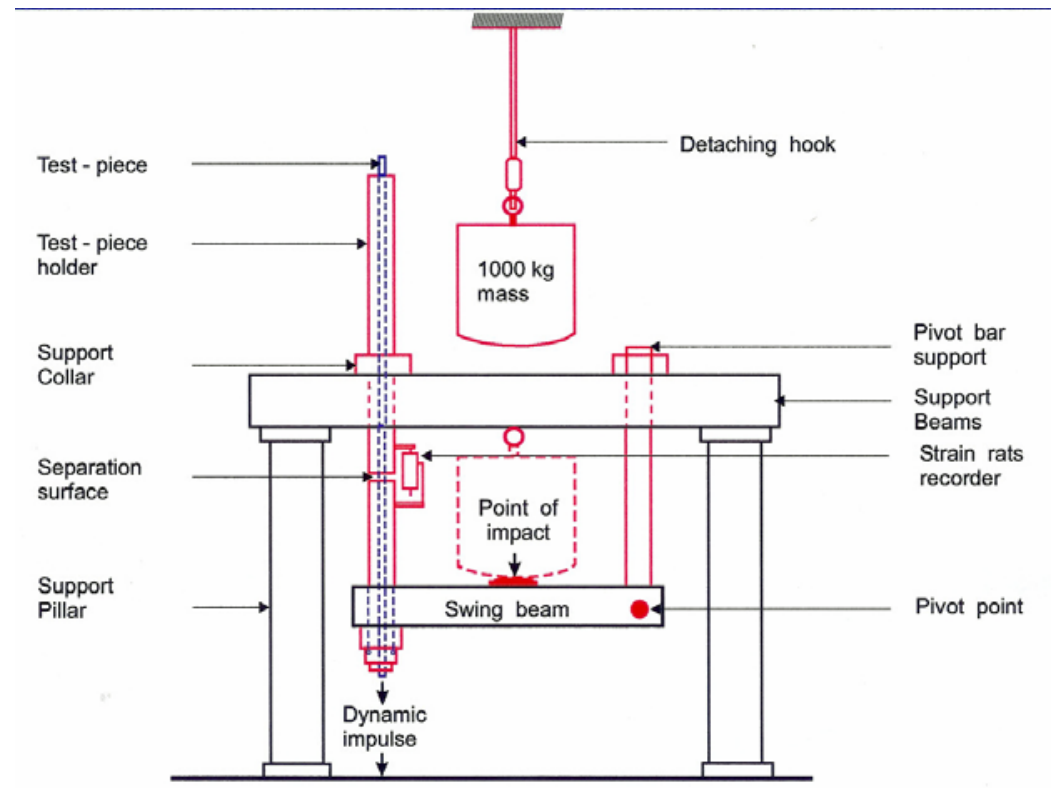

Figure 2 General view of the dynamic testing facility for rockbolts, after Stacey and Ortlepp (1999)

Ortlepp and Stacey (1997) provide the details for Set-up \#1. The rig employed the impact of a free moving mass (drop weight of 1048 or $2706 \mathrm{~kg}$ ) onto a load distribution system which then loads the surface support systems. In practice, a load distribution pyramid of steel-encased concrete blocks was applied on a "simulated rock mass". The upper layers and lowest layer of blocks are restrained to preventing spreading. This is to maintain load transfer to the lower block and support element. This rock mass consists of concrete blocks that are in contact with the support. The support sample is hung from support beams using $22 \mathrm{~mm}$ diameter cone bolts. The choice of cone bolts was made in order to ensure that failure of bolts did not occur during the tests. This was necessary given the objective to determine the performance of containment support systems. The drop weight test facility could test "panels" of $1.6 \times 1.6 \mathrm{~m}$. The test facility was designed to be capable of input energies up to $70 \mathrm{~kJ}$ and with impact loading velocities up to $8 \mathrm{~m} / \mathrm{s}$. 
Instrumentation was limited to direct tape measurements in elevation, still photographs (before/after) and video recordings. The degree of damage inflicted to the mesh was assessed by counting broken wires and visual examinations. The number of concrete bricks broken also provided a crude assessment of inflicted damage.

The main advantages of this rig are: the relatively inexpensive set-up; the configuration provides for consistent and repeatable tests; the rig could undertake multiple tests on the same surface element and the use of a simple load distribution system.

The system has had limited instrumentation used for the tests and no effort is made to quantify energy losses in the system. Player (2005) argued that that the use of multiple block geometries in multiple layers results in a complex load distribution system that limits the repeatability of the tests, particularly at higher input energies. Furthermore, the determination of the capability of the support system does not take into consideration the way energy is transferred from the blocks to the support system, Player (2005).

A total of 55 tests were reported in GAP 221. These included tests on weld mesh, diamond mesh, diamond mesh and lacing, as well as shotcrete (mesh reinforced, polypropylene-reinforced, using $30 \mathrm{~mm}$ Dramix and non-reinforced). At the time of a site visit in September 2005 the rig was no longer in operation.

\subsubsection{SIMRAC project 616}

Set-Up \#1 was also used for the purposes of SIMRAC project 616. According to Güler et al. (2001) the setup was modified in order to represent the rock mass, Figure 3. This was achieved by using a volume of relatively hard bricks, suspended by $20 \mathrm{~mm}$ bolts, and confined at the bottom layer by a reinforcing frame. The use of interlocking pavement bricks allowed them to be linked in a competent assembly. This resulted in a simulated rock structure whereby the weakest planes were normal to the applied impact load. The bricks were assembled around four tendons inside the confining frame. Consequently, the tendons were tensioned and confinement was applied by the confining frame, so that the supporting frame could be removed.

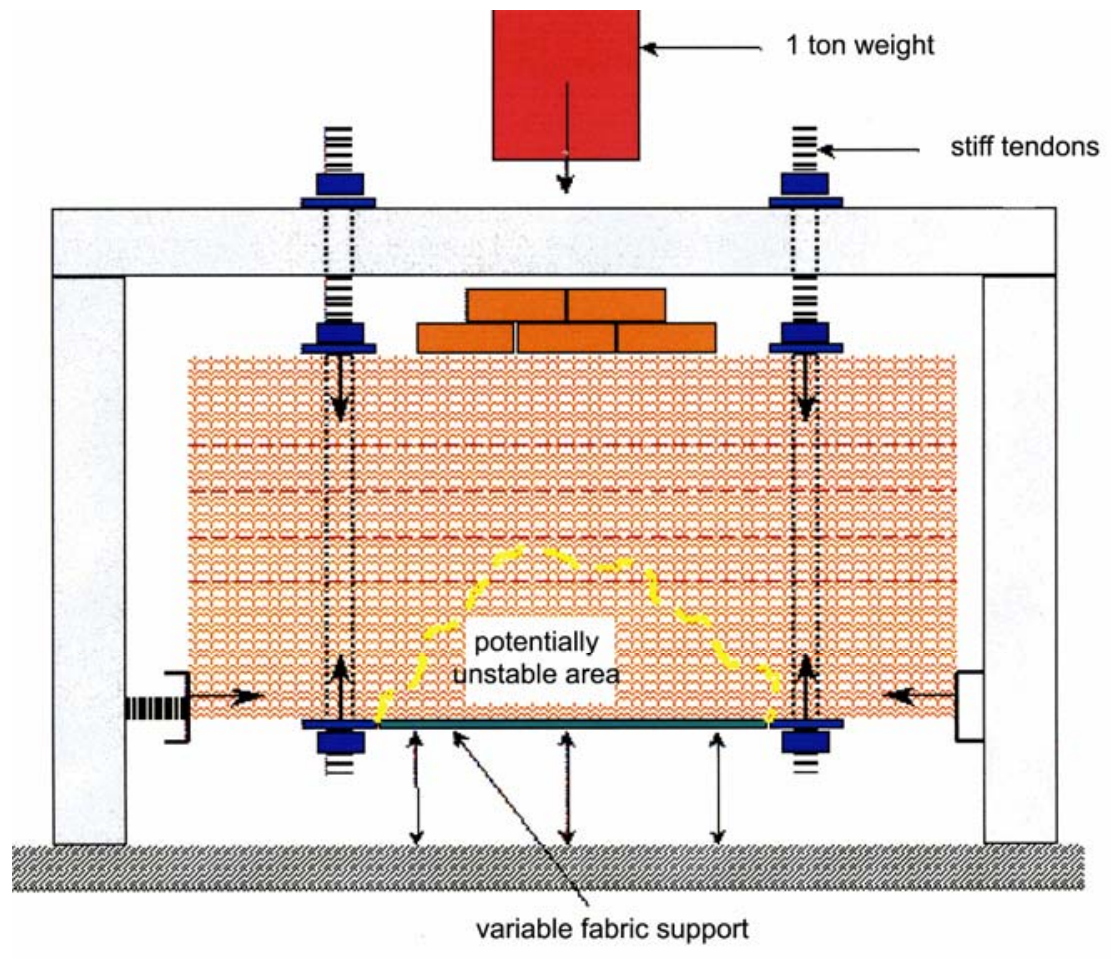

Figure 3 Test frame with artificial rock mass and support system, after Güler et al. (2001)

Resulting deformations were recorded using a monitoring frame that contained nine vertical telescopic bars touching nine specific locations along the bottom of the assembly. Following each impact load both, the maximum as well as the permanent deformations, were recorded. The difference between maximum and permanent deformation is representative of dynamic elastic behavior. Furthermore, a Ground Motion 
Monitor (GMM) with eight geophones was used to record the peak particle velocities (PPVs) along the bottom of the testing assembly. This facilitated the recording of PPVs generated by repeated dynamic loading.

The following conclusions from this testing program were reached: Deformations accumulate with the number of impacts. Magnitude of accumulated deformations controls the stability of individual fragments. Maximum deformation before failure is increased by the use of a structural membrane. The magnitude of accumulated deformation is strongly reduced by the presence of lacing and/or shotcrete. Use of fibrereinforced shotcrete (approximately $100 \mathrm{~mm}$ ) resulted in substantial improvement in energy absorption. A large drop height produces more deformation than a number of small drop heights with equivalent total impact energy.

\subsubsection{Set-Up \#2: Reinforcing Element Testing from Drop Test Impact}

Ortlepp and Stacey (1998) addressed the performance of reinforcement units under dynamic loading. This was done by modifying rig set-up \#1 previously used to test panels. This testing strategy was based on the observation that rockburst damage frequently involved the rapid ejection of a limited thickness of rock from the excavation wall. It was noted that reinforcement elements would fracture at or close to this separation surface. Given that the dead-weight of ejected rock was often much smaller than the strength of the rockbolts that were damaged, it was argued that this demonstrated that the kinetic energy of the limited mass of rock was significantly greater than provided by gravity.

The dimensions of the reinforcement units to be tested were established by making the ejectable portion $600 \mathrm{~mm}$ long. This resulted in an embedment length ranging from $600 \mathrm{~mm}$ for "rigid rockbolts" (assuming a critical bond length less than $600 \mathrm{~mm}$ ) and up to 2400 for friction rockbolts (i.e. where resistance was due to sliding).

Simulated drill holes were created using two lengths of $63 \mathrm{~mm}$ outside diameter and $40 \mathrm{~mm}$ inside diameter thick walled steel tubing butted together for the testing of fully grouted bolts. These tests used a standardised grout (shear strength $9.1 \pm 1.27 \mathrm{MPa}$ ). A very strong fine grained "concrete" made from 1:2 mix of high alumina cement and screened $\leq 1.0 \mathrm{~mm}$ hammer-milled andesite aggregate was pressed around a $25 \mathrm{~mm}$ diameter steel rod to form a semi annulus in each half of the $93 \mathrm{~mm}$ split tube. After the concrete was allowed to cure the steel rod was removed and the two half shells were bonded and clamped together.

The impulse was applied to the anvil collar of the specimen holder by the "knuckled-end" of a very stiff $820 \mathrm{~kg}$ mass swing-beam of $1.0 \mathrm{~m}$ effective length. As shown in the diagram it was possible to apply an energy pulse at a known impact velocity to the midpoint of the swing beam by simply controlling the drop height of the impacting mass. Because the inertial mass of the swing beam $(820 \mathrm{~kg})$ was considerably less than that of the striking mass (1048 or $2706 \mathrm{~kg}$ ), the transfer of momentum function ensured that the initial velocity of the beam midpoint was much greater than the velocity of the drop weight at impact. The midpoint start velocity was doubled at the point of application of the load to test piece by the simple geometry of the swing beam arrangement. The actual strain rate imparted to the test piece was recorded using a gravitydriven cylindrical chart recorder.

Ortlepp and Stacey (1998) report that during the testing program it was recognised that the system was relatively soft and it would not have been possible to achieve rupture of the tested units. This prompted a reconfiguration of the rig. Heavier, stiffened double channel beams supported on four pillars of concretefilled heavy duty $250 \mathrm{~mm}$ diameter steel pipes were positioned to reduce the bending span from 2.7 to $0.4 \mathrm{~m}$. The softest element in the modified assembly was the $90 \mathrm{~mm}$ diameter pivot bar, which has a calculated stiffness of $1.4 \mathrm{MN} / \mathrm{mm}$ and an ultimate strength of $1900 \mathrm{kN}$.

The facility functions by using a free falling mass to impact a stationary "swing beam". The impact force is translated from the swing beam to the outside of a thick wall pipe (that simulates borehole conditions) and the head of the bolt being tested. During the test it is assumed that $1 / 2$ of the energy imparted to the mid-point of the swing beam by the impact of the drop weight goes into stressing the tendon under test and the other half is dissipated in the pivot bar. Player (2005) suggests that this could have been verified using appropriate instrumentation (load cells). The split in energy distribution between the specimen and pivot bar will change with time during the impact. The true energy split depends on the relative stiffness of the specimen to the pivot bar, and yielding of either the reinforcing element and/or its yielding mechanism within the borehole. 
As a result of the drop weight falling on the swing beam it was possible to generate impact velocities up to $20 \mathrm{~m} / \mathrm{s}$. In this set-up the tendons were grouted into steel tubes or installed in boreholes formed in simulated rock in steel tubes.

Player (2005) has argued that sources of variation in load application come from the combination of a swing beam and pivot bar, and the potential for non-uniformity in impact of the free moving mass on to the swing beam. It is not obvious how critical the effects of these variations are on the tests.

The main advantages of this configuration are the fact that the set-up is relatively inexpensive and that it provides a repeatable methodology for testing reinforcement units under dynamic loads. The configuration is quite versatile (the same rig was used in Set-Up \#1 for support) and relatively easy to set-up (can conduct several tests). Furthermore, the tube dimensions provide the same order confinement as provided by the rock mass. The load is applied to the outside of the pipe and would be a reasonable representation of the load applied by ejected rock to the borehole and grout within, but not the surface hardware. Tests can be undertaken in double embedment configuration.

The major limitations of the facility are the processes by which load is transferred within the facility and the relative stiffness of its components. Other shortcomings include the limited instrumentation and basic calculation methodology used to assess the energy absorption capacity of the rockbolts. Load cells could have been located to record the anchor and collar forces. No strain gauges are installed for the measurement of swing beam or support beam deflection and calculation of energy loss, and the beam does not load the surface restraint component of a reinforcement system.

\subsection{SIMRAC dynamic stope test facility}

This dynamic support test unit was designed and constructed for the SIMRAC project GAP 611 by Ortlepp (2001) of SRK Consulting. This was subsequently updated during the course of another SIMRAC project GAP 818 (Ortlepp and Swart, 2002). The set-up (see Figure 4) which attempts to replicate the configuration of a typical South African gold mine longwall stope is at the Savuka Mine (AngloGold West Wits Operations Satellite training centre) near Johannesburg in South Africa.

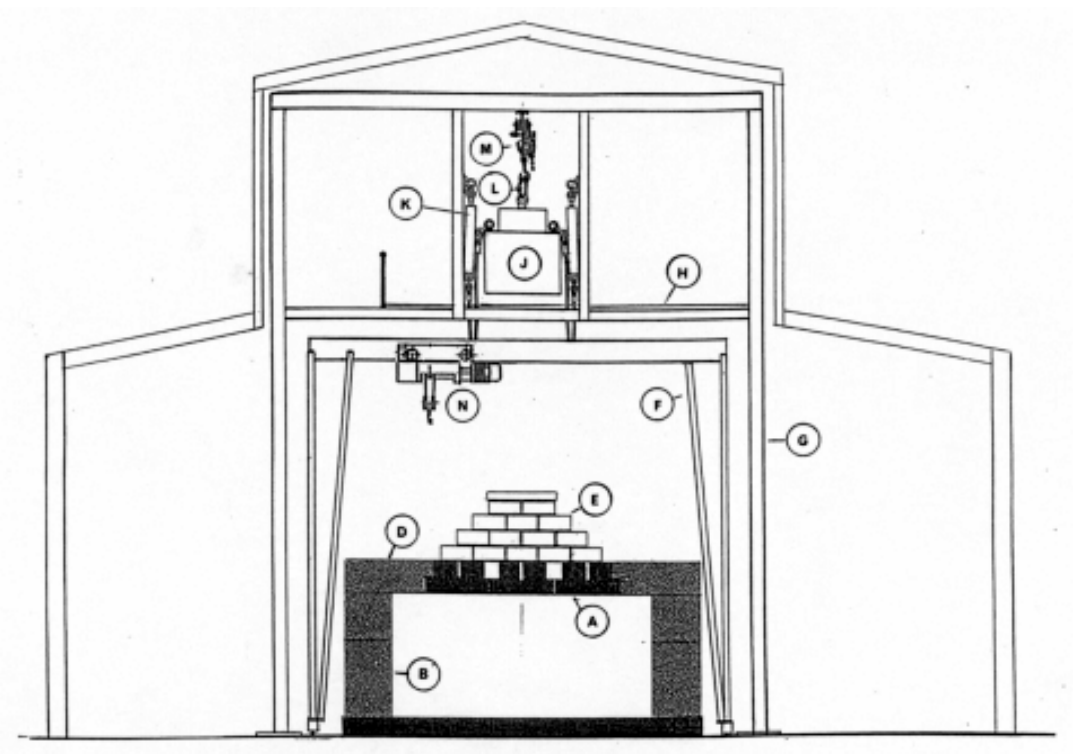

$\mathrm{A}=$ collapsible roof

$\mathrm{B}=$ corner column

$\mathrm{C}=$ deck

$\mathrm{D}=$ side beam

$\mathrm{E}=$ load distribution pyramid

$\mathrm{F}=$ portal crane $\mathrm{M}=10 \mathrm{t}$ hoist

$\mathrm{G}=$ main support column

$\mathrm{H}=$ floor

$\mathrm{J}=$ drop weight

$\mathrm{K}=$ load arrestor

$\mathrm{L}=$ quick release shackle

$\mathrm{N}=5 \mathrm{t}$ electric hoist

$\mathrm{O}=$ berthing platform for drop weight

Figure 4 General view of test facility, after Ortlepp and Swart (2002)

The area that can be supported by the test is $5.5 \times 6.5 \mathrm{~m}$. This allows the testing of support systems, although the system is configured for the testing of props. The central roof area of $3 \times 3 \mathrm{~m}$ consists of three Voussoir beams, each comprising 12 robustly reinforced concrete blocks $1.0 \mathrm{~m}$ wide and $0.25 \mathrm{~m}$ thick. These blocks are held together under a $200 \mathrm{kN}$ load. During the passage of the dynamic impulsive force, the blocks may collapse individually or in batches. Of interest is the option to employ a set of blocks that display irregular 
steeply-contoured undersurfaces similar to the rough stepped roof in a deep-level stope. On top of the roof is a pyramid of steel clad concrete blocks that represent the upper hanging wall strata. The impulsive energy is generated by dropping a $10000 \mathrm{~kg}$ steel mass on top of the load distribution pyramid. If the ball is dropped from a maximum height of $3.0 \mathrm{~m}$ it results in an energy impulse of $300 \mathrm{~kJ}$ at $7.7 \mathrm{~m} / \mathrm{s}$. The height of the pillars is $1.4 \mathrm{~m}$, although the use of $0.6 \mathrm{~m}$ extension columns increases the height of the test stope to $2.0 \mathrm{~m}$.

The advantages of this arrangement are the well engineered structure and an experienced crew and the capacity for repeatable tests. The system is limited in that it cannot test reinforcement units. Instrumentation is somewhat limited (i.e. tape measures and video).

\subsection{SRK/Duraset wedge-block loading device}

The impetus for the development of the wedge-block loading device was the recognition that there was no dynamic testing machine in South Africa that could accommodate embedded cable test specimens longer than $1.2 \mathrm{~m}$ long. The developed SRK/Duraset displacement conversion device would employ the $300 \mathrm{~kJ}$ drop weight SIMRAC stope support test facility.

The wedge-block loading device consists of two guided thrust blocks with inclined faces, with a wedge driving them apart, Figure 5. The wedge converts vertical displacement into horizontal displacement. As the test-piece is supported in the horizontal position it is possible to test bolts longer than $5 \mathrm{~m}$. The hollow bar from which the specimen holder is made has an outside diameter of $80 \mathrm{~mm}$ and an inside diameter of $50 \mathrm{~mm}$. This is considered to adequately represent the compressibility of the partly-relaxed rock surrounding a hard rock excavation. The mass of the drop weight is $10000 \mathrm{~kg}$. The height of the drop can be varied between 0.4 to $4 \mathrm{~m}$. maximum energy available is about $390 \mathrm{~kJ}$ when the weight falls from a height of $4 \mathrm{~m}$ to generate an impact velocity of $8.9 \mathrm{~m} / \mathrm{s}$. Electronic monitoring devices record the very rapid loads and displacements on the bolts providing for measure of the energy consumed during the test or at breakpoint.
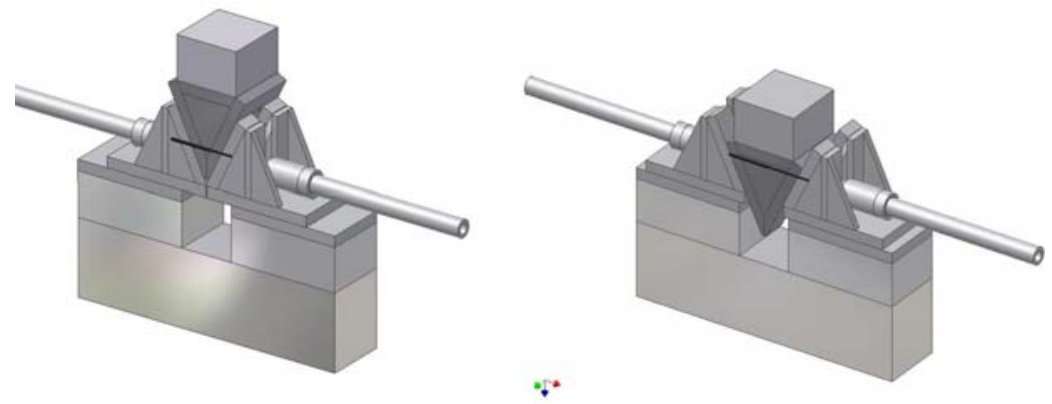

Figure 5 a) wedge-block loading device before impact; b) after impact after Ortlepp and Erasmus (2005)

Advantages include that the device can accommodate longer bolts/cables than other devices. Stiffness in the axial direction is arguably of the same magnitude as the rigidity of the rock mass. The wedge-block loading apparatus is a relatively inexpensive. This rig is limited in that it only tests the reinforcement element and not a system. Limited test results are available.

\subsection{GRC support element test facility}

A drop test facility for impact testing of the face restraint support systems, constructed at Creighton Mine's old \#7 shaft (Kaiser et al., 1996), is shown in Figure 6. The objective was to test shotcrete under impact loads perceived to represent moderate size rockbursts. Financed by the Canadian Rockburst Research Program, the facility used direct impact of a free moving mass onto the support element. 


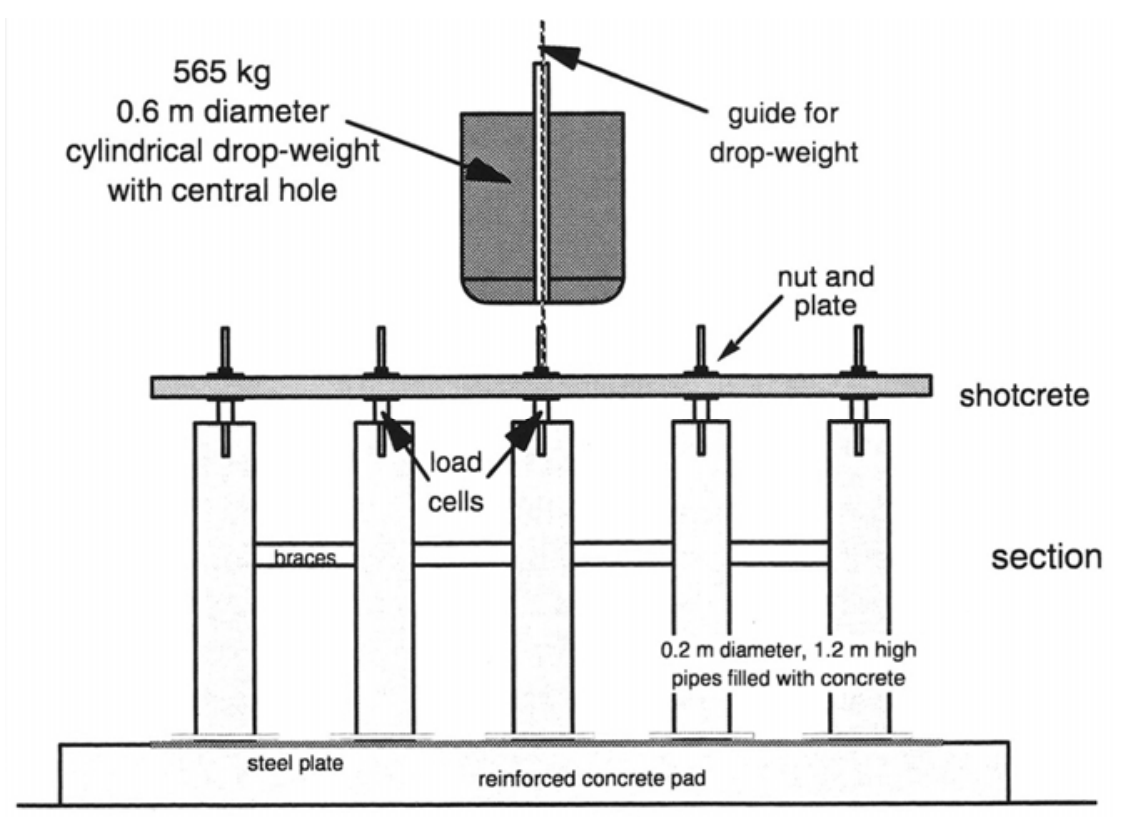

\section{Figure 6 The Creighton set-up}

A series of concrete columns was set up to support mesh and shotcrete panels to be tested, using a drop weight operated by a hoist and release mechanism. The panels rested on support plates anchored to the columns and these could be tensioned from above. Load cells were installed between the columns and the lower support plates. The impact of the load was monitored with accelerometers, the load cells, and displacement measuring instruments. The rig had a maximum drop height of $4 \mathrm{~m}$ that would imply a potential velocity of $8.8 \mathrm{~m} / \mathrm{s}$, with a kinetic energy of $21.9 \mathrm{~kJ}$. The columns used to support the test panels were relatively stiff and dissipated little of the total impact energy.

The main advantages were the quick set-up time as it was possible to simply change panels between tests; Once the facility was established, testing of support elements should have been relatively cheap; The element size was reasonable to represent edge conditions and the rig was well instrumented.

Limitations included the integration of the reinforcement elements to the support element (fibrecrete panel) and the energy absorption calculation process. The facility tests the performance of the surface support element from a direct impact of a falling mass and not the interaction of the surface attachment with the reinforcing element.

The set-up was used to undertake impact tests on bolted shotcrete panels. The instrumentation identified the peak loads carried by the bolts and the impact energies dissipated by the mesh reinforced shotcrete panels and supporting columns. Following the testing program the set-up has now been dismantled.

\subsection{GRC weight drop test}

This apparatus is reported in Yi and Kaiser (1994) and was used to conduct dynamic tests on a small steel rod with cushions. The apparatus was used to demonstrate the influence of multiple impact loading, resulting in plastic strain accumulation, on rockbolts. There is no evidence that the apparatus has received any more attention.

A small steel rod $(6.35 \mathrm{~mm}$ diameter and $2.44 \mathrm{~m}$ length with a $2.28 \mathrm{~m}$ free length) was protected from bending caused by a dropping weight. The weights were 18.36 and $48.494 \mathrm{~kg}$ at heights of 0.1 and $0.3 \mathrm{~m}$. The facility used scaled down bolts.

Its advantages include the simple and inexpensive set-up that requires minimum set-up time. The limitations are: drop height and drop weight were small; multiple drops were required to fail rods; it could only test single reinforcement units; it could not account for installation. There were limited data on shortened bolts and no records of more recent work. 


\subsection{Noranda technology centre drop unit}

This rig was designed by Mirarco (Kaiser/Maloney) for Noranda Inc. Gaudreau et al. (2004) provide the configuration of the rig. Following the closure of the Noranda Technology Centre the rig was transferred to Natural Resources Canada in the CANMET laboratories in Ottawa. The rig was upgraded, most significantly by introducing a $3000 \mathrm{~kg}$ weight.

A $1000 \mathrm{~kg}$ weight was dropped down the shaft of a bolt to impact on the surface plate. The maximum fall distance was $2 \mathrm{~m}$ and the maximum potential energy was $20 \mathrm{~kJ}$. This facility was used primary to test cone bolts, which were installed in a test tube of an internal diameter of $38 \mathrm{~mm}$ and external diameter of $47.5 \mathrm{~mm}$. The rig used $1.7 \mathrm{~m}$ long bolts which were spun into two Fosroc $915 \mathrm{~mm}$ (fast) and $35 \mathrm{~mm}$ diameter (slow) resin cartridges.

The advantages were that it was relatively fast and cheap and could take full scale bolts in simulated boreholes. The main limitations were load transfer to the reinforcement unit through the surface hardware. The system did not account for system stiffness and energy losses. A major concern was the drop height and mass used. This necessitated multiple hits to fail a bolt, complicating the interpretation of the results.

The set-up was designed to test grouted bolts and, in particular, modified cone bolts. These provide the most comprehensive results. Plouffe et al. (2007) report that the rig has been successfully modified to test friction bolts.

\subsection{WASM dynamic test facility}

The Western Australian School of Mines (WASM) test facility is situated in Kalgoorlie in Western Australia and is arguably the state of the art testing rig and unequivocally the more expensive. Phase 1 of this project has been financed by MERIWA, the Western Australia School of Mines and several other partners.

The basic premise of the WASM arrangement is that dropping a reinforced simulated rock mass (including the bolt and surface hardware) on an impact surface results in a dynamic loading and deformation of the reinforcement. In the WASM set-up the simulated rock mass comprises the drop beam and the steel rings of the test facility prior to impact, while the simulated ejected rock is represented by the steel rings integrated with the borehole. It should be noted that the simulated ejected rock is in fact decelerated. The degree of deceleration is controlled by the properties of the reinforcement system but also of the buffers. Player et al. (2004) use a series of hydraulic buffers to protect the foundations of the testing rig and provide a consistent response. On the other hand, it follows that the buffers absorb some of the total energy at impact. Player et al. (2004) describe the operation of the rig, which is shown in Figure 7.

The WASM system is by far the most instrumented of the dynamic rigs as it measures forces (using load cells), displacements (using motion sensors) and includes post processing of high speed digital video camera. Accelerometers are used to estimate velocities and displacements and strain gauges are used to measure strains in the beam. Data are recorded electronically to facilitate reviewing, filtering and analysis over selected time intervals.

The advantages are: Integration of the simulated rock mass to the reinforcement system; tube dimensions provide the same order confinement as provided by the rock mass; large input energy and state of the art instrumentation. This is a well engineered testing facility with the capacity to calculate the energies absorbed by the various components at any time during a test. The facility has recently been adapted to test surface support and has provided useful comparative results for two mesh types (welded wire mesh and high tensile wire chain link mesh) Villaescusa (2007). 


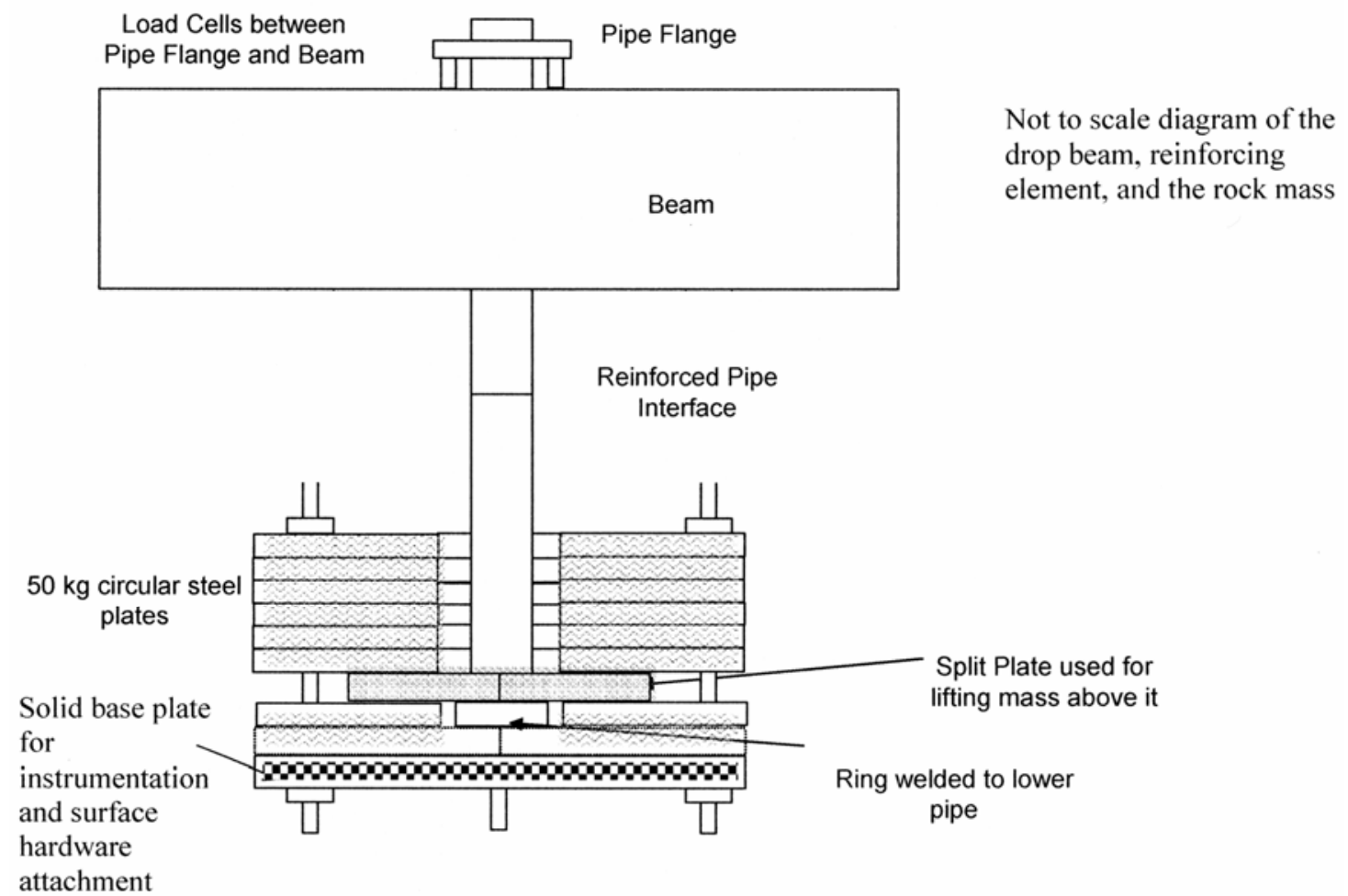

Figure 7 WASM test facility (schematic), after Player et al. (2004)

\subsection{MIRARCO impact test}

Recently MIRARCO constructed a large-scale, outdoor dynamic testing facility at Laurentian University. The main objective is to conduct impact tests on full size $(1.5 \times 2.7 \mathrm{~m})$ screen. There is no available published information on the rig. The information has been provided by Maloney (2005).

A large circular mass (up to $565 \mathrm{~kg}$ ) with a diameter of $600 \mathrm{~mm}$ is dropped, using an electro-magnetic release mechanism, from heights of 0.25 to 3 metres onto full-size mesh panels. Load distribution is through the use of hexagonal concrete blocks onto the mesh in the impact area. Load cells at each of the four interior columns record the resulting impact and the downward deflection of the mesh at its centre is monitored using a displacement measuring rotary potentiometer (in retraction mode). The movement of the drop weight is measured using a velocity transducer.

The advantages include that is relatively easy to set-up and not very expensive to operate. The element size is reasonable in terms of representing edge conditions and the whole set up is well instrumented. Its limitations include the integration of the reinforcement element with the support element and the energy absorption calculation process. The facility tests the performance of the surface support element from a direct impact of a falling mass and not the interaction of the surface attachment with the reinforcing element.

\subsection{Testing rig capabilities}

Table 3 summarises the reported or current capability of rigs to test different reinforcement units and support systems. Attention is drawn to the fact that there are sometimes different configurations of the same rig. Table 3 is an effort to provide an accurate picture of the capabilities of a rig. It should be realised, however that it is quite possible to upgrade any rig and also that a rig can fall into disuse. 
Table 3 Comparison of the dynamic load simulation methods used for each trial

\begin{tabular}{|c|c|c|c|c|c|c|c|c|}
\hline Rig & $\begin{array}{l}\text { Common } \\
\text { Name }\end{array}$ & $\begin{array}{c}\text { Individual } \\
\text { Reinforcement } \\
\text { Units }\end{array}$ & $\begin{array}{l}\text { Surface } \\
\text { Support } \\
\text { Systems } \\
\text { (panels) }\end{array}$ & Props & $\begin{array}{l}\text { Max. } \\
\text { Drop } \\
\text { Weight } \\
\text { (kg) }\end{array}$ & $\begin{array}{l}\text { Maximum } \\
\text { Height of } \\
\text { Drop (m) }\end{array}$ & $\begin{array}{l}\text { Maximum } \\
\text { Energy } \\
\text { Available } \\
\text { (kJ) }\end{array}$ & $\begin{array}{c}\text { Maximum } \\
\text { Impact } \\
\text { Velocity } \\
\text { (m/s) }\end{array}$ \\
\hline 1 & Terratek & $\begin{array}{l}\text { Short bolts up } \\
\text { to } 1.6 \mathrm{~m}\end{array}$ & N/A & $\begin{array}{l}\text { Props up to } \\
1.6 \mathrm{~m}\end{array}$ & & 0.6 & & 3 \\
\hline $2 a$ & $\begin{array}{l}\text { SRK Drop } \\
\text { weight test } \\
\text { facility } \\
\text { Set-Up \#1 }\end{array}$ & N/A & $\begin{array}{l}1.6 \mathrm{x} \\
1.6 \mathrm{~m}\end{array}$ & & $\begin{array}{c}1048 \\
(2706)\end{array}$ & $\begin{array}{l}4 \\
4\end{array}$ & $\begin{array}{l}41.12 \\
(81.5)\end{array}$ & $\begin{array}{c}8.8 \\
(7.3)\end{array}$ \\
\hline $2 b$ & $\begin{array}{l}\text { SRK Drop } \\
\text { weight test } \\
\text { facility Set- } \\
\text { Up \#2 }\end{array}$ & $\begin{array}{l}\text { Rockbolts and } \\
\text { cable bolts }\end{array}$ & N/A & & $\begin{array}{l}1048 \\
(2706)\end{array}$ & 4 & & 20 \\
\hline 3 & $\begin{array}{l}\text { SIMRAC } \\
\text { Dynamic } \\
\text { Stope Test } \\
\text { Facility }\end{array}$ & N/A & $3 \times 3 \mathrm{~m}$ & $\begin{array}{l}\text { Props up to } \\
2 \mathrm{~m} \text { (with } \\
\text { extensions) }\end{array}$ & 10000 & 3 & 300 & 7.7 \\
\hline 4 & $\begin{array}{l}\text { GRC- } \\
\text { Laurentian }\end{array}$ & $\begin{array}{l}\text { Steel Rod } \\
2.44 \mathrm{~m} \text { long }\end{array}$ & N/A & N/A & 48.494 & 0.3 & 0.14 & 2.43 \\
\hline 5 & $\begin{array}{l}\text { GRC- } \\
\text { Creighton }\end{array}$ & N/A & $\begin{array}{c}1.2 \mathrm{x} \\
1.2 \mathrm{~m} \\
\text { diamond } \\
\text { patterns; } \\
\text { shotcrete } \\
\text { panels } \\
1.5 \mathrm{x} \\
2.75 \mathrm{~m}\end{array}$ & N/A & 565 & 4 & 21.9 & 8.8 \\
\hline $6 a$ & NTC & $\begin{array}{l}\text { Bolts up to } \\
1.7 \mathrm{~m} \text { long }\end{array}$ & N/A & N/A & 1000 & 2 & 20 & 1.5 \\
\hline $6 b$ & $\begin{array}{l}\text { NTC- } \\
\text { CANMET }\end{array}$ & $\begin{array}{l}\text { Bolts up to } \\
1.7 \mathrm{~m} \text { long }\end{array}$ & N/A & N/A & 3000 & 2 & 58.86 & 6.26 \\
\hline 7 & WASM & $\begin{array}{l}\text { Bolts and } \\
\text { Cables up to } \\
2.4 \mathrm{~m} \text { long }\end{array}$ & $1 \times 1 \mathrm{~m}$ & N/A & 4500 & 6 & 225 & 10 \\
\hline 8 & $\begin{array}{l}\text { Wedge- } \\
\text { Block } \\
\text { Loading } \\
\text { Device }\end{array}$ & $\begin{array}{l}\text { Bolts and } \\
\text { Cables up to } \\
5.5 \mathrm{~m} \text { long }\end{array}$ & No & No & 10000 & 4 & 390 & 8.9 \\
\hline 9 & MIRARCO & N/A & $\begin{array}{l}1.5 \times 2.7 \\
\mathrm{~m} \text { screen }\end{array}$ & N/A & 565 & 3 & 16.63 & 7.67 \\
\hline
\end{tabular}




\subsubsection{Loading}

The loading mechanism employed by a testing rig is of importance. Although there is a general understanding that none of the loading techniques duplicate the rockburst phenomenon, as they involve a single pulse (followed by rapidly dampened oscillation) as opposed to the low frequency vibration of large seismic events, there are valuable lessons to be gained from this type of experiment.

Use of the NTC rig assumes that a weight guided down the shaft of a bolt and loading the head of a reinforcement unit is an adequate representation of a seismic load. The Creighton rig drops a load upon the support system to be tested. The SRK and SIMRAC rigs employ a load distribution pyramid of interlocking concrete blocks to load the system under investigation. The SRK reinforcement set-up assumes an equal distribution of the impact load between the pivot bar and the reinforcement unit.

The WASM system drops a simulated rock mass to test a reinforcement unit. Buffers are used to absorb some of the impact. The reinforcement unit deforms resulting in either control the 'ejected rock' displacement (by absorption of the energy) or failure. The comprehensive monitoring strategy of the WASM rig allows calculation of the energy absorbed by the various components of the rig at any given instant.

\subsubsection{Capabilities}

It is clear that different information can be sourced from the use of tests that focus on reinforcement compared with rigs that test surface support systems. While there is need for both types of test, at the current time there is no single rig that is actually in operation that can test the interaction of reinforcement and surface support.

\subsubsection{Extrapolation of results}

The stated objective of most testing rigs is to determine either the capacity of a reinforcement unit or support system or provide a basis for comparison. The first observation is that the set-ups differ quite a lot and that in itself has raised questions on the ability to transfer the applicability of results from rig to rig. On the other hand there has been little duplication of testing programs at the different rigs. This in itself has been a major limitation.

Another important issue is how to extrapolate the results of the rigs to actual site conditions. At the present time this has received limited attention. A further issue that has yet to be addressed is how to extrapolate from the relative controlled environment of the rigs into the less controlled, but arguably still controlled environment of simulated rockburst studies.

\section{Discussion}

Essentially four possible techniques can be used for assessing the performance of rock reinforcement units and support systems under dynamic conditions: laboratory tests on core; drop test facilities; simulated rockburst experiments and passive monitoring and back analysis of case studies.

Of the four approaches, laboratory tests on core have received limited attention. This could be due to the lack of comprehensive similitude studies that can arguably aid in the extrapolation of results and understanding of scale effects etc. These tests may have some benefit in terms of testing isolated parameters like the effect of confinement. However, their potential to contribute to the development of design guidelines for dynamic resistant support systems is considered very unlikely.

It is recognised that the drop test technique is a very crude simulation of the seismic loading mechanism. The different variations of the test rely on a single impulse delivered to the reinforcement and support using different principles and apparatus. The replication of rock mass - support interaction is, in most test rigs, arguably poor and the conditions under which the tests are conducted have no similitude to in-situ conditions (rock mass, stress, boundary conditions, etc. There is a case to be made that these tests provide an adequate comparison of different reinforcement units or systems under the same test conditions. Variations in the way that load distribution is applied at the different rigs can eventually be addressed.

Despite the limitations of the impact tests, test rigs can provide repeatable results. It follows that the experimental data can possibly be correlated to in-situ conditions and become usable for design purposes. 
The main advantage of the drop test approach lies in its capacity to perform a relatively large number of tests at reasonable cost, without interfering with mining operations. Consequently, it is somewhat surprising that more data is not available from the existing rigs.

Globally, it is suggested that there would be great value in standardising test procedures and seeking collaboration to allow for the data from different sources to be pooled together. Developing or implementing different test procedures that do not address the main limitations and are not widely accepted, runs the risk of developing isolated pools of data that would have limited value and application.

It can be argued that simulated rockburst experiments, when well designed and successfully implemented, can provide dynamic loads that resemble seismic events. Nevertheless, it is recognised that there are important differences between the two types of generated shockwaves. The high cost, difficult logistics and variations in the design of such trials has hindered the generation of an adequate database that could provide the necessary empirical data to be used for further design. Standardising experimentation procedures and increasing the database of results will be a step towards better understanding of the capability of dynamic resistant support systems.

Testing individual components of ground support systems can assist in establishing a relative ranking of these components under controlled conditions. However, if the objective is to understand how the support system will perform in-situ, it is critical to test the system, with all its components linked together, rather than testing individual components separately, as a system's performance is generally only as strong as its weakest link.

The most realistic assessment of ground support systems to dynamic loads is the passive monitoring of real events. Unfortunately, as these events are unpredictable in time and space, they are rarely adequately instrumented "a priori". Therefore, little quantitative data in terms of ground support energy absorption from real seismic events has been collected to date. Careful documentation of case studies, even in the absence of complete instrumentation data, will ultimately be required to quantify the performance of support systems.

\section{Conclusion}

Based on the available information, or rather because of the absence of data, it can be argued that the laboratory testing of core technique is very limited and does not provide data directly useable for design purposes. The three other techniques (drop test facilities, simulated rockburst experiments and passive monitoring and back analysis of case studies) can provide complementary data. Drop tests can offer a less accurate representation of reality, but more abundant results, simulated rockbursts give more realistic but fewer results and the scarce data from passive monitoring and case studies are ultimately required to provide the reality check and final calibration.

It is suggested that the argument should not be about determining which approach is the best but rather to recognise that they are all useful, complementary and could all contribute to the development of design guidelines. The key is to link the results from the three techniques. As the database from both drop tests and simulated rockbursts need further results, there would be a clear advantages in seeking agreement on standard procedures between different organisations involved in this area of research and starting to pool the results together.

It is concluded that the "path forward" to advance the objective of forecasting the performance of ground support systems subjected to dynamic loading will necessitate that a standardised drop-test procedure is adopted. This could mean the construction of new or the modification of existing facilities to comply with the standardised testing guidelines and work towards increasing and documenting the database of drop tests. In parallel, it is imperative that some sort of standard is prepared for simulating rockbursts and contributing to a more comprehensive database. As more mines operate under conditions of high stress it should be possible to establish a database of case histories and passive monitoring of support systems under dynamic loading. Finally, the real breakthrough will come about once more work is done towards linking of drop-test results, simulated rockbursts results and case histories. This could eventually result in the development of comprehensive empirical design rules. 


\section{Acknowledgements}

This review was made possible by the Deep Mining Research Consortium, which provided the guidelines for this work. The authors acknowledge the collaboration provided by several people. In particular, Dr. G. Swan and B. Simser, M. Plouffe, Prof. E. Villaescusa, D. Heal, S. Maloney, Prof. T.R. Stacey, D. O’Donnell, D. Ortlepp, D.J. Adams, Prof. D. Tannant and Dr. R. Durham. They have all provided clarifications and access to non-published information.

\section{References}

Andrieux, P., Turichshev, A., O’Connor, P., Brummer, R.K. (2005) Dynamic testing with explosive charges of rockburst-resistant ground support systems at the Fraser Nickel Mine. Itasca Consulting Canada Inc Report to Falconbridge Limited Mine Technical Services; Final Version, September 2005, Sudbury Canada.

Archibald, J.F., Baidoe, J.P. and Katsabanis, P.T. (2003) Rockburst damage mitigation benefits deriving from use of spray-on rock linings. $3^{\text {rd }}$ International Seminar on Surface Support Liners: Thin Spray-on Liners, Shotcrete and Mesh, Quebec City, Canada, 25th-27th August 2003, Section 19.

Brown, E.T. (2004). The dynamic environment of ground support and reinforcement. Ground Support in Mining and Underground Construction. Villasecusa \& Potvin (eds), pp. 3-16.

Espley, S.J., Heilig, J. and Moreau, L.H. (2002) Assessment of the dynamic capacity of liners for application in highlystressed mining environments at Inco limited. International Seminar on Surface Support Liners, Johannesburg, South Africa.

Gaudreau, D., Aubertin, M. and Simon, R. (2004) Performance of tendon support systems submitted to dynamic loading. Ground Support in Mining and Underground Construction. Villaescusa and Potvin (eds), pp. 299-312.

Güler, G., Kuijpers, J.S., Wojno, L., Milev, A. and Haile, A. (2001) Determine the effect of repeated dynamic loading on the performance of tunnel support systems. SIMRAC, GAP 616.

Hadjigeorgiou, J., Potvin Y. (2006) Critical review of Dynamic Testing of Support Systems (1995-2005). Technical report Submitted to CAMIRO, p. 63.

Hagan, T.O., Milev, A.M., Spottiswoode, S.M., Hildyard, M.W., Grodner, M., Rorke, A.J., Finnie, G.J., Reddy, N., Haile, A.T., Le Bron, K.B. and Grave, D.M. (2001) Simulated rockburst experiment - an overview. The Journal of The South African Institute of Mining and Metallurgy, August 2001, pp. 217-222.

Haile, A.T. and Le Bron, K. (2001) Simulated rockburst experiment - evaluation of rock bolt reinforcement performance. The Journal of the South African Institute of Mining and Metallurgy, August 2001, pp. $247-251$.

Heal, D. (2005) Ground support for rockbursting conditions. Australian Centre for Geomechanics Course No.0505; Advanced Geomechanics, Section 8, Perth, August 3-5, 2005.

Hildyard, M.W. and Milev, A.M. (2001) Simulated rockburst experiment: Numerical back-analysis of seismic wave interaction with the tunnel. The Journal of The South African Institute of Mining and Metallurgy, August 2001, pp. 223-234.

Kaiser, P.K., McCreath D.R. and Tannant D.D. (1996) Canadian Rockburst Support Handbook. Canadian Rockburst Research Program.

Maloney, S. (2005) Personal Communication.

Mansurov, V. (1993) Laboratory experiments: their role in the problem of rockburst prediction. Chapter 32. In Comprehensive Rock Engineering, pp. 745-769.

Ortlepp, W.D. and Swart, A.H. (2002) Extended use of the Savuka dynamic test facility to improve material and analytical technology in deep-level stope support. SIMRAC Report GAP 818.

Ortlepp, W.D. (2001) Performance testing of dynamic stope support test facility at Savuka. SIMRAC Report GAP 611.

Ortlepp, W.D. and Erasmus, P.N. (2005) Dynamic testing of a yielding cable anchors. $3^{\text {rd }}$ Southern African Rock Engineering Symposium.

Ortlepp, W.D. and Stacey, T.R. (1997) Testing of tunnel support: dynamic load testing of rock support containment systems. SIMRAC GAP Project 221.

Ortlepp, W.D. and T.R. Stacey (1998) Testing of tunnel support: dynamic load testing of rockbolt elements to provide data for safer support design. SIMRAC GAP Project 423.

Player, J. (2005) Dynamic testing of ground support. Australian Centre for Geomechanics Course No.0505; Advanced Geomechanics, Section 9, Perth, August 3-5, 2005.

Player, J.R., Villaescusa, E. and Thompson, A.G. (2004) Dynamic testing of rock reinforcement using the momentum transfer concept. Ground Support in Mining and Underground Construction. Villaescusa and Potvin (eds), pp. 327-339.

Plouffe, M., Anderson, T. and Judge, K. (2007) Dynamic and static testing of tendons - Development of a testing protocol for friction bolts, Natural Resources Canada, CANMET - Mining and Mineral Sciences Laboratories report CANMET-MMSL 06-033-B(CR), 21 p. plus appendixes. 
Reddy, N. and Spottiswoode, S.M. (2001) The influence of geology on a simulated rockburst. The Journal of the South African Institute of Mining and Metallurgy, August 2001, pp. 267-272.

Swan, G. (2003) Critical review of Phase 2, WSIB Project \#00 007 Report, Falconbridge Ltd Memorandum to Professor James Archibald, Sudbury Ontario, January 20, 2003.

Stacey, T.R. and Ortlepp, W.D. (1999) Retainment support for dynamic events in mining. Rock Support and Reinforcement Practice in Mining, pp. 329-333.

Tannant, D.D., Brummer, R.K. and Kaiser, P.K. (1994a) Response of rockbolts to nearby blasts. IV South American Congress on Rock Mechanics, pp. 241-248.

Tannant, D.D., McDowell, G.M. and McCreath, D.R. (1994b) Shotcrete performance during simulated rockbursts. International Workshop on Applied Rockburst Research, Santiago.

Tannant, D.D, McDowell, G.M., Brummer, R.K. and Kaiser, P.K. (1993) Ejection velocities measured during a rockburst simulation experiment. International Symposium on Rockbursts and Seismicity in Mines, Kingston, pp. 129-133.

Villaescusa, E. (2007) Ground support research at the WA School of Mines. Canadian Institute of Mining \& Metallurgy, Annual General Meeting, Montreal.

Yi, X. and Kaiser, P.K. (1994). Impact testing for rockbolt design in rockburst conditions. Intl. J. Rock Mech. \& Geomech. Abstr. Vol. 31, No.6, pp. 671-685. 